\title{
ОФТАЛЬМОЛОГІЯ
}

(C) О.Г. Хомишин, М.В. Турчин, Л.І. Терещенко, 2018

УДК 617.735

\section{Доцільність використання оксикаротиноїдів та екстракту чорниці у комплексній терапії паціснтів із вологою формою вікової макулярної дегенерації}

\author{
О.Г. Хомишин ${ }^{1}$, М.В. Турчин ${ }^{2}$, Л.І. Терещенко ${ }^{3}$ \\ medic77@ukr.net \\ ${ }^{1}$ Медичний иентр «Віасан», ${ }^{2}$ Тернопільський державний медичний університет імені
I.Я. Горбачевського, медичний факультет, кафедра оториноларингології та офтальмологї,
${ }^{3}$ ТРТМО, Тернопіль
}

\section{Реферат}

Збільшення захворюваності на вікову макулярну дегенерацію (ВМД) є гострою проблемою охорони здоров'я. Вплив оксикаротиноїдів, антоціанів, а також ряду вітамінів та мінералів на патогенетичні ланки розвитку та прогресування вікової макулярної дегенерації спонукали до вивчення клінічної ефективності використання комбінованих нутріцевтичний препаратів у поєднанні з інтравітреальними ін'єкціями анти-VEGF фактора та періодичним проведенням вазопротекторної, ноотропної, ретинопротекторної терапії у пацієнтів з ВМД. Саме тому дана робота передбачає оцінити ефективність використання комбінованих нутріцевтиків у комплексній терапії вологої форми ВМД з метою профілактики прогресування вікової макулярної дегенерації. Результати дослідження свідчать про достовірно кращий стабілізаційний ефект лікування у пацієнтів основної групи, які отримували препарат «Слезавіт» як дієтичну добавку до раціону харчування, тобто додаткове джерело оксикаротиноїдів (лютеїну, зеаксантину) і антоціанів, а також водо- і жиророзчинних вітамінів та мікроелементів у комплексній терапії вологої форми вікової макулярної дегенерації.

Ключові слова: вікова макулярна дегенерація, оксикаротиноїди, екстракт чорниці, антоціани, нутріцевтики

Feasibility of using oxycarotenoids and blueberry extract in complex therapy of patients with a wet form of AMD KhomyshynO.H., ${ }^{1}$ TurchynM.V., ${ }^{2}$, Tereshchenko L.I. ${ }^{3}$

LLC "Medical Center "Viasan",' TSMU named after Gorbachevsky, medical faculty, Department of Otorhinolaryngology and Ophthalmology, ${ }^{2}$ TRTMO ${ }^{3}$, Ternopil

Abstract

An increase in the incidence of age-related macular degeneration (AMD) is an acute public health problem. The effect of oxycarotenoides, anthocyanins, and also a number of vitamins and minerals on the pathogenetic links in the development and progression of age-related macular degeneration led to the study of the clinical efficacy of the use of combined nutraceutical medications in combination with intravitreal injections of anti-VEGF factor and periodic vasoprotective, nootropic, retinal protective therapy in patients with AMD. That is why this work is supposed to evaluate the effectiveness of using combined nutraceuticals in complex therapy of wet form of AMD in order to prevent the progression of age-related macular degeneration. The results of the study indicate a significantly better stabilization effect of treatment in the patients of the main group who received the drug "Slezavit" as a dietary supplement to the dietary structure as an additional source of oxycarotenoids (lutein, zeaxanthin) and anthocyanins, as well as water and fat-soluble vitamins and micro-elements in the complex therapy of patients with a wet form of age-related macular degeneration.

Key words: age-related macular degeneration, oxycarotenoids, blueberry extract, anthocyanins, nutraceuticals

Вступ. Згідно з останніми даними, на вікову макулярну дегенерацію (ВМД) страждають близько 20\% жителів країн Західної Свропи у віці старше 65 років $[1,4,5,9,19]$. Основними патогенетичними ланками пошкодження пігментного епітелію сітківки є мітохондріальна дисфункція, оксидативний стрес, активація комплемента, запалення та аномальна структура міжклітинного матриксу. Такі зміни призводять до збільшення продукції факторів росту і матричних металопротеїназ. Фактори росту сприяють росту новоутворених судин, а металопротеїнази викликають появу дефектів у мембрані Бруха. Внаслідок цього хоріоїдальна неоваскуляризація поширюється під пігментний епітелій та нейросенсорну сітківку. Кінцевим етапом розвитку процесу є формування субретинального дисковидного фіброзного рубця в центральному відділі сітківки та значна втрата зорових функцій $[1,4,9,13,14,16,18]$. Система антиоксидантного захисту сітківки включає в себе неферментні системи (вітаміни А, C, Е та глутатіон), ферментні системи (альфа-ліпоєва кислота, змішані кароти- 
ноїди, коензим Q10, біофлавоноїди), мікроелементи (мідь, цинк, марганець, селен) і кофактори (вітаміни В1, В2, B6, В10, B12) [2,3,7,8,16-19]. Особливе значення в реалізації антиоксидантного захисту відводиться оксикаротиноїдам - лютеїну і зеаксантину, надходження яких в організм напряму пов'язане 3 харчуванням, оскільки в організмі вони не синтезуються $[4,13,18]$. Оскільки розвиток ВМД в значній мірі пов'язаний з фототоксичною дією короткохвильового світла, а також накопиченням в пігментному епітелії ліпофусцину і фототоксичних сполук, прийом лютеїну і зеаксантину при даному захворюванні $\epsilon$ патогенетично виправданий $[4,8,13,16-19]$. Важливо, що оксикаротиноїди сконцентровані в центрі сітківки, куди припадає максимальне світлове навантаження. Вони відповідають за фільтрацію синьої частини спектру та зв'язування радикалів кисню, що утворюються в результаті фотоокислення [4,7-9,13,14,19]. За даними різних авторів, антоціани чорниці, окрім вираженого антиоксидантного ефекту, сприяють поліпшенню реологічних властивостей крові, оскільки знижують тонус судинної стінки і сприяють іiі зміцненню (ефект обумовлений участю даних речовин у регуляції біосинтезу колагену), зменшують тромбоутворення, прискорюють регенерацію родопсину i активацію ферментів сітківки, тим самим знижуючи ризик розвитку та прогресування дистрофії сітківки [5,8-11,14].

Мета дослідження. Дослідження доцільності використання оксикаротиноїдів та екстракту чорниці в комплексній терапії пацієнтів 3 вологою формою ВМД у поєднанні 3 інтравітреальними ін'єкціями анти-VEGF фактора та періодичним проведенням вазопротекторної, ноотропної, ретинопротекторної терапії.

Матеріали та методи. Нами обстежено 26 пацієнтів (35 очей) у віці 60-80 років. Спостереження проводилось протягом 2 років. Основну групу склали 12 осіб (19 очей), контрольну - 14 осіб (16 очей). Усім пацієнтам проведено загальне офтальмологічне обстеження, включаючи візометрію, авторефкератометрію, біомікроскопію, пряму офтальмоскопію, оцінку центрального поля зору (тест Амслера), статичну периметрію, ОСТ, ФАГ; дано рекомендації щодо раціонального харчування та ведення здорового способу життя. Серед пацієнтів основної групи діагностовано відшарування ПЕС, НЕС у 47,4\% досліджуваних (9 очей), наявність субретинальної неоваскулярної мембрани у $36,8 \%$ (7 очей) та ексудативно-геморагічного відшарування ПЕС, HEC у 15,8\% (3 ока). Пацієнти основної групи поряд 3 антиангінальною терапією та традиційною ретинопротекторною, судинопоширюючою та ноотропною терапією (2 рази на рік) приймали препа- рат «Слезавіт» компанії «World Medicine» (вітамін $\mathrm{C}-60,0$ мг, екстракт чорниці - 60,0 мг, вітамін Е 10,0 мг, лютеїн - 10,0 мг, цинку оксид- 10,0 мг, вітамін В2 - 3,0 мг, вітамін В6 - 2,0 мг, вітамін В1 1,5 мг, зеаксантин - 1,0 мг, вітамін А - 1,0 мг, сульфат міді - 1,0 мг, хром - 50,0 мкг, селен - 25,0 мкг) по 1 капсулі в день протягом тривалого часу (4-6 місяців), переважно у періодах між традиційними медикаментозними курсами лікування та 3 перервами від 1 до 3 місяців. Критеріями оцінки ефективності лікування була позитивна динаміка та стабільність гостроти зору, офтальмоскопічної картини, статичної периметрії, даних ОСТ і ФАГ. У контрольній групі досліджуваних діагностовано відшарування ПЕС, НЕС у 50,0\% пацієнтів (8 очей), наявність субретинальної неоваскулярної мембрани у $37,5 \%$ (6 очей) та ексудативно-геморагічного відшарування ПЕС, НЕС у 12,5\% (2 ока). Всі пацієнти даної групи приймали оксикаротиноїди в різних дозуваннях або антоціани протягом періоду спостереження тривалими курсами (2-6 місяців) з 1-3 місячними перервами. Пацієнти контрольної групи 3 ВМД також отримували антиангінальну терапію та періодично (2 рази на рік) проходили курс традиційної ретинопротекторної, судинопоширюючої та ноотропної терапії.

Результати досліджень та їх обговорення. Серед пацієнтів основної групи позитивна динаміка гостроти зору, офтальмоскопічної картини, статичної периметрії, даних ОСТ і ФАГ спостерігалась у 63,1\% пацієнтів (12 очей) зі стабілізацією клінічних показників протягом всього періоду спостереження, відсутня динаміка у 31,6\% (6 очей), прогресування захворювання відбувалось 5,3\% (1 око). У пацієнтів контрольної групи виявлено покращення показників візометрії, офтальмоскопії, статичної периметрії, даних ОСТ і ФАГ у $37,5 \%$ осіб (6 очей), відсутність погіршення без явної позитивної динаміки у 43,75\% пацієнтів (6 очей) та негативну динаміку за даними ОСТ, ФАГ, офтальмоскопічної картини та скарг у 18,75\% пацієнтів (3 ока).

Висновки. Результати дослідження дозволяють рекомендувати препарат «Слезавіт» в якості дієтичної добавки до раціону харчування як додаткове джерело оксикаротиноїдів (лютеїну, зеаксантину) i антоціанів, а також водо- і жиророзчинних вітамінів та мікроелементів у комплексній терапії пацієнтів 3 вологою формою ВМД. Беручи до уваги збільшення захворюваності ВМД, населення повинно бути проінформоване про важливість не лише правильного харчування та здорового способу життя, а також необхідності періодичного прийому комбінованих нутріцевтиків з метою профілактики розвитку та прогресування ВМД.

Інформація про конфлікт інтересів. Автори заявляють про відсутність конфлікту інтересів при виконанні наукового дослідження та підготовці даної статті.

Інформація про фінансування. ТОВ «Медичний центр «Віасан» надав медичне обладнання для проведення ряду офтальмологічних досліджень, зокрема оптичної когерентної томографії (апарат STRATUS 3000, Zeiss). Автори гарантують, що не отримували ніяких винагород ні в якій формі від фірм-виробників 
лікарських препаратів, медичного обладнання та матеріалів, у тому числі конкурентів, здатних вплинути на результати роботи.

Особистий внесок кожного автора у виконання роботи:

Хомишин О.Г. - автор дослідження, проведення ОСТ, збір, обробка та оцінка даних дослідження;

Турчин М.B. - куратор дослідження, виконання інтравітреальних ін'єкцій анти-VEGF фактора;

Терещенко Л.І. - підбір вазопротекторної, ноотропної, ретинопротекторної терапії, збір, обробка та оцінка даних дослідження.

\section{Список використаної літератури}

1. Akuffo K, Nolan J, Howard A, Moran R, Stack J, Klein R, et al. Sustained supplementation and monitored response with differing carotenoid formulations in early age-related macular degeneration. Eye. 2015;29(7):902912.

2. Evans J, Lawrenson J. Antioxidant vitamin and mineral supplements for preventing age-related macular degeneration. Cochrane Database of Systematic Reviews. 2017;5:32-4.

3. Johnson E, Mcdonald K, Caldarella S, Chung H, Troen A, Snodderly D. Cognitive findings of an exploratory trial of docosahexaenoic acid and lutein supplementation in older women. Nutritional Neuroscience. 2008;11(2):75-83.

4. Garther DC. Lutein and zeaxanthin - new perspectives for preservation of eye health. Clinical Ophthalmology. 2015;1:13-21.

5. Kiselyova TM, Lagutina YuM, Kravchuk OA. Influence of anthocyanosides on visual functions and hemodynamics of patients with non-exudative age-related macular degeneration. VI All-Russian school of ophthalmology. SB science. tr M. 2017:452-4.

6. Klein R, Meuer S, Myers C, Buitendijk G, Rochtchina E, Choudhury F, et al. Harmonizing the Classification of Age-related Macular Degeneration in the Three-Continent AMD Consortium. Ophthalmic Epidemiology. 2014;21(1):14-23.

7. Kon JY. Modern ideas about the role of lutein carotenoid in the nutrition of young children. Pediatrics. 2012;91(1):96-102.

8. Kumari N, Ruth E, Michael R. Carotenoids and co-antioxidants in age-related maculopathy: Design and Methods. Ophthalm. Epidemiol. 2013;15:389-401.

9. Latalska M, Matysik-Wouniak A, Bylina J. Wet age-related macular degeneration (wet AMD) in rural and urban inhabitants in south-eastern Poland. Ann. Agric Environ Med. 2013;19:726-30.

10. Matsunaga N, Chikaraishi Y, Shimazawa M, et al. () Vacciniummyrtillus (Bilberry) Extracts Reduce Angiogenesis In Vitro and In Vivo. Evid. Based Complement. Alternat. Med. 2014;7(1):47-56.

11. Novosti MOZ Ukraini. (2016) Available at:http://www.moz.gov.ua.

12. Romanenko IA. Effectiveness of Bilberry Preparations in Ophthalmology: Clinical Observations. Clinical Ophthalmology. 2011;1:32-38.

13. Saksonova EO Lutein and zeaxanthin are the main components of the antioxidant eye protection system. Clinical Ophthalmology. 2015;2:124-138.

14. Schmier JK, Covert DW, Lau EC.Patterns and costs associated with progression of age-related macular degeneration. Am. J.Ophthalmol. 2012;154(4):675-81.

15. Stavitskay TV. Extracts of Vaccinium myrtillus in the ophthalmology. Clinical Ophthalmology. 2013;3:8688.

16. Sun XD, Wang FH. Optimizing the individual treatment of neovascular age-related macular degeneration. Zhonghua Yan Ke Za Zhi. 2014;48(10):867-69.

17. Trieschmann M, Beatty S, Nolan J. Changes in macular pigment optical density and serum concentrations of its constituent carotenoids following supplemental lutein and zeaxanthin: the Luna stady. Experimental Eye Reseach. 2017;84:718-28.

18. Wang H, Barteselli G, Freeman WR. Temporal pattern of resolution/reccurence of choroidal neovascularization during bevacizumab therapy for wet age-related macular degeneration. Int. J. Ophthalmol. 2013;6(5):600-5. 19. Huang Y, Dou H, Huang F, Xu X, Zou Z, Lu X, et al. Changes following supplementation with lutein and zeaxanthin in retinal function in eyes with early age-related macular degeneration: a randomised, double-blind, placebo-controlled trial. British Journal of Ophthalmology. 2014;99(3):371-375.

Стаття надійшла до редакції: 13.03 .2018 р. 